\title{
Four Syllables for Slaying and Repelling: A Tibetan Vajrabhairava Practice from Recently Recovered Manuscripts of the "Lost" Book of Rwa (Rwa pod)
}

\section{Introduction}

In 2001, the late Elliot Sperling published a brief but incisive article entitled “'Orientalism' and Aspects of Violence in the Tibetan Tradition," marking one of the first steps in the dismantling of a persistent romance, a fanciful stereotype of Tibetan Buddhism as the quintessential religion of peace and nonviolence and the Dalai Lamas, past and present, as paragons of Gandhian pacifism. ${ }^{1}$ In Sperling's effort in that essay to bring much-needed context and critical sensitivity to a challenging topic - and, in turn, to humanize Tibetans, their history, and their culture he did well to remind us of the messy realities of the human condition, of worldly existence, of those "aspects of life that breed strife and discord." And in that messiness, he argued, Tibetan Buddhism was made "a vehicle for power in the arena of world history, first for Tangut emperors, then for Mongol, Chinese, and Manchu rulers."2 Indeed, Tibetan Buddhism is rich with an abundance of methods and techniques for the attainment of power, both for religious and political ends. ${ }^{3}$ Inasmuch as there are Tibetan rituals, too numerous to count, for acquiring the wisdom and benevolence of the buddhas and bodhisattvas, for achieving goodwill, peace, and healing, there are also nearly an equal number (if not more) designed for coercion, suppression, and violent harm. They include the usual tantric initiations, ritual offerings, ceremonies employing wrathful deities, and so forth; but also rituals to repel and suppress aggressive forces, intoning hostile mantra and dhāraṇi spells, casting ritual "cake bombs" (gtor

\footnotetext{
1 In Imagining Tibet: Perceptions, Projections, and Fantasies, eds. Thierry Dodin and Heinz Räther (Boston: Wisdom Publications, 2001), 317-29 [324]. This article was based on a paper presented in 1996 at an international symposium held in Bonn, Germany.

2 Sperling, “'Orientalism' and Aspects of Violence in the Tibetan Tradition,” in Imagining Tibet: Perceptions, Projections, and Fantasies, eds. Thierry Dodin and Heinz Räther (Boston: Wisdom Publications, 2001), 319 (emphasis added).

3 Several examples of the latter in Tibetan history are surveyed in Bryan J. Cuevas, "The Politics of Magical Warfare," in Faith and Empire: Art and Politics in Tibetan Buddhism, ed. Karl Debreczeny (New York: Rubin Museum of Art, 2019), 171-89.
}

¿ Open Access. (C) 2021 Bryan J. Cuevas, published by De Gruyter. (cc) BY-NC-ND This work is licensed under a Creative Commons Attribution-NonCommercial-NoDerivatives 4.0 International License.

https://doi.org/10.1515/9783110674088-011 
zor) made of dough or some other less wholesome ingredient (e.g. animal feces and the like), and preparing effigies personifying the enemy to be manipulated like some form of Buddhist voodoo doll. ${ }^{4}$ In a word, these are the weaponized vehicles of Tibetan Buddhist power. And in the interests of crosscultural comparison, we could reasonably describe them all as examples of Buddhist magic and perhaps more appropriately, as Buddhist sorcery - a fair though not entirely unproblematic rendering of the Tibetan word mngon spyod, Sanskrit abhicāra. ${ }^{5}$

\section{The Vajrabhairava Sorcerer}

In Tibetan Buddhist history there is one exemplary master of such rites who became the archetype of the Buddhist sorcerer, notorious across the centuries as

4 On the ritual use of effigies (Tib. linga), see Bryan J. Cuevas, "Illustrations of Human Effigies in Tibetan Ritual Texts: With Remarks on Specific Anatomical Figures and Their Possible Iconographic Source," Journal of the Royal Asiatic Society 21, no. 1 (2011): 73-97 and sources cited therein.

5 The two classic introductions to the category of magic and sorcery in the Indian Sanskrit traditions remain Teun Goudriaan, Māyā Divine and Human: A Study of Magic and its Religious Foundations in Sanskrit Texts, with Particular Attention to a Fragment on Viṣnu's Māyā Preserved in Bali (Delhi: Motilal Banarsidass, 1978) and Hans-Georg Türstig, "The Indian Sorcery Called Abhicāra," Wiener Zeitschrift fur die Kunde Südasiens 29 (1985): 69-117; also of value is Gudrun Bühnemann, "The Six Rites of Magic," in Tantra in Practice, ed. David Gordon White (Princeton, NJ: Princeton University Press, 2000), 447-62 and various articles in Knut A. Jacobsen, ed., Yoga Powers: Extraordinary Capacities Attained Through Meditation and Concentration (Leiden: Brill, 2012). For magic in Buddhism generally, see Luis O. Gómez, "The Bodhisattva as WonderWorker," in Prajñāpāramitā and Related Systems: Studies in Honor of Edward Conze, ed. Lewis Lancaster (Berkeley: Berkeley Buddhist Studies Series, 1977), 221-61; Phyllis Granoff, "The Ambiguity of Miracles: Buddhist Understandings of Supernatural Power," East and West 46, nos. 1/2 (1996): 79-96; Bradley S. Clough, "The Higher Knowledges in the Pāli Nikāyas and Vinaya," Journal of the International Association of Buddhist Studies 33, nos. 1/2 (2010/2011): 409-33; and most recently, Thomas Nathan Patton, The Buddha's Wizards: Magic, Protection, and Healing in Burmese Buddhism (New York: Columbia University Press, 2018). On magic and sorcery in Buddhist tantric traditions, see especially Stephan Beyer, The Cult of Tārā: Magic and Ritual in Tibet (Berkeley, CA: University of California Press, 1973); Peter Schwieger, "Black Magic in Tibetan Buddhism," in Historical and Philological Studies of China's Western Regions, no. 3, ed. Shen Weirong (Beijing: Science Press, 2010): 169-85; Bryan J. Cuevas, "The Calf's Nipple (Be'u bum) of Ju Mipam ('Ju Mi pham): A Handbook of Tibetan Ritual Magic," in Tibetan Ritual, ed. José I. Cabezón (New York: Oxford University Press, 2010), 165-86; and Iain Sinclair, "War Magic and Just War in Indian Tantric Buddhism,” Social Analysis 58, no. 1 (2014): 149-66. 
a fearsome "lord of magical power" (mthu stobs dbang phyug) as well as a consummate translator (lo tsā $b a$ ) of esoteric Buddhist scripture, specifically the tantras of the fierce divinities Vajrabhairava and Yamāri/Yamāntaka. This is Rwa lo tsā ba Rdo rje grags, who began his career in the early eleventh century in the southwestern Tibetan valley known today as Nyalam (gnya' lam), near the Nepalese border. In the legends of his unusually long and wondrous life, he is said to have made four extended trips to Nepal and twice visited India to obtain and translate these tantras and their attendant practices (sädhana, maṇdala, yantra, homa, etc.). His translations of the Vajrabhairava cycle in particular (later accepted as authoritative and officially incorporated into the Tibetan Canon) ${ }^{6}$ were accomplished under the tutelage of two nebulous Nepali scholars referred to in the literature by the rather generic names Guru Bha ro phyag rdum ("Bha ro maimed hand," Skt. alias Dīpaṃkaraśrī) and paṇdita Bal po Thugs rje chen po (Skt. Mahākaruṇika, alias Dīpaṃkararakșita; also Tib. Me tsa/Mi dza/Mañja [g]ling pa). ${ }^{7}$ Confused by these names, some early Tibetan biographers of the Rwa tradition (rwa lugs) mistakenly conflated the two as one teacher, as we shall see in one example below.

In Tibet, Rwa lo is most famous, infamous in fact, not so much for his translation efforts but for having "liberated" (i.e. killed) through magical means more than a dozen of his Buddhist rivals and others he perceived as antagonistic to his

6 Translations and revisions by Rwa lo tsā ba in the Kangyur: Derge 467, De bzhin gshegs pa thams cad kyi sku gsung thugs gshin rje nag po’i rgyud (Sarvatathāgata-kāya-vāk-citta-kṛṣnayamāritantra), rgyud, ja, 134v1-151v4; Derge 468, Dpal rdo rje 'jigs byed chen po'i rgyud (Śn-vajramahābhairava-tantra), rgyud, ja, 151v4-164r1; Derge 472 (cf. Derge 1996), Te’u lo pa’i cho ga (Cucchundara-kalpa), rgyud, ja, 174r2-174v7; Derge 473, Gshin rje’i gshed dgra nag po'i 'khor lo las thams cad grub par byed pa'i rgyud kyi rgyal po (Yamārikrṣna-karmasarvacakra-siddhakara-tantrarājā), rgyud, ja, 175r1-185v7. Tengyur translations: Derge 1976, Rdo rje 'jigs byed zhal gcig phyag gnyis paii sgrub pai thabs (Vajrabhairavaikānanadvibhuja-sādhana), rgyud, mi, 147v5-150r2; Derge 1983, Dkyil 'khor gyi cho ga (Mandalavidhi), rgyud, mi, 166r7-171v4; Derge 1994, Dpal rdo rje 'jigs byed kyi sgrub pa'i thabs (Śrī-vajrabhairava-sādhana), rgyud, mi, 190r2-190v4; Derge 1995, Rdo rje 'jigs byed kyi tshogs kyi 'khor lo (Vajrabhairava-ganacakra), rgyud, mi, 190v4-192v5; Derge 1996 (cf. Derge 472); Tstshu tstshunda ra’i rtog pa (Cucchundara-kalpa), rgyud, mi, 192v5-193v5; Derge 1997, Rdo rje 'jigs byed chen po'i sbyin sreg gi cho ga (Mahāvajrabhairava-homavidhi), rgyud, mi, 193v5-196v3; Narthang 1700, Las kyi gshin rje chos kyi rgyal po'i bsgrub thabs (Karmayamadharmaräja-sädhana) rgyud 'grel, pi, 422v6-424v4; Narthang 3589, Gshin rje gshed nag po'i 'khor lo'i gsal byed (Krș̣nayamāri-cakroddyota), rgyud 'grel, zhu, 95v5-98r4.

7 For further details about these two teachers with references to relevant primary sources, see Bryan J. Cuevas, "Rva lo tsā ba and His Biographers," in The Illuminating Mirror: Tibetan Studies in Honour of Per K. Sørensen on the Ocassion of His 65th Birthday, eds. Olaf Czaja and Guntram Hazod (Wiesbaden: Dr. Ludwig Reichert Verlag, 2015), 57-79; also, Ra Yeshé Sengé, The AllPervading Melodious Drumbeat: The Life of Ra Lotsawa, trans. Bryan J. Cuevas (New York: Penguin Classics, 2015), xxx-xxxiii. 
spiritual mission. He did this by utilizing the tantric procedures centered on Vajrabhairava and his alter ego Yamāri/Yamāntaka. It is well known that the tantras, broadly speaking, offer a vast assortment of ritual mechanisms for achieving a seemingly limitless array of supernormal powers (siddhi) to be used for a variety of objectives, both worldly (laukika) and otherworldly (lokottara). In the Buddhist tantras, such goals include, but are certainly not limited to, obtaining the elixir of longevity and achievement of the status of "wizard" (vidyādhara); flying through the sky and ascending into the heavens of the devas and asuras; assuming multiple forms; destroying the defilements (āśravakșaya) that prevent liberation; realizing the stages of a bodhisattva; achieving eloquence and great physical strength; becoming invisible; traveling long distances swiftly and without exhaustion; controlling demons and other harmful forces; prevailing over others; punishing wicked people and vanquishing enemies; and achieving so many other similarly magical and wondrous feats.

What is unusual in the case of Rwa lo tsā ba, however, is that his biographers consistently glorify the more aggressive and ethically ambiguous of these tantric ritual aims - Buddhist sorcery, in other words. Without question, the Vajrabhairava tantras, to which Rwa lo was so fervently devoted, are replete with measures for coercing (nigraha), immobilizing (stambhana), causing dissension (vidveșaṇa), eradicating and driving away (uccātana), bewildering (mohana), inflicting illness (vyādhikāraṇa), and annihilating (māraṇa). ${ }^{8}$ The long-established justification for these sorts of hostile actions, which is cited explicitly and repeatedly both in the tantras themselves and in the literature promoting Rwa lo tsā ba's legacy, is that such apparent violence actually signals a profound compassionate wisdom that directly perceives the emptiness (śunyatā), the nonduality (advaya), of self and other, friends and enemies. On the level of practice, moreover, Rwa lo tsā ba's apparent deviant actions are proffered as an expedient strategy, a bodhisattva's skillful means (upāyakauśalya) to liberate beings who are dangerously deluded or confused and to place them on the path to buddhahood. When, in this way, nondual wisdom or gnosis (advayajñāna) is combined with the compassionate skillful means of the bodhisattva, as these Buddhist texts consistently remind us, there is ultimately no violence committed, since there is no real victim of the act and no real agent of the action. Put another way, again from the tradition's point of view, the primary object signified by Rwa lo tsā ba's lethal behavior is not literally his exercise of brute physical harm, but rather his

8 For examples, see translation in Bulcsu Siklós, The Vajrabhairava Tantras: Tibetan and Mongolian Versions, English Translation and Annotations (Tring: The Institute of Buddhist Studies, 1996), esp. 31-35, 44-47, 55-56, and 75-76. 
enlightened experience of nondual gnosis. Such experience is invariably claimed by his devoted followers as verification of Rwa lo tsā ba's status as a fully enlightened and compassionate buddha. This is precisely how the tradition sympathetic to Rwa lo as a saintly Buddhist hero makes sense of his seemingly hostile and violent deeds. We see this earnestly dramatized in the celebrated Rwa lo rnam thar ("The Life of Rwa lo"), an extravagant hagiographical work ascribed by tradition to Rwa lo tsā ba's grandnephew, Rwa Ye shes seng ge (fl. ca. 1150), but of uncertain date and provenance. ${ }^{9}$ Rwa Ye shes seng ge hailed from the valley of Khu lung in Gtsang and became known as the first patriarch of the Western Rwa tradition (rwa nub lugs). ${ }^{10}$

The Rwa lo rnam thar is mostly acclaimed for its sensational and occasionally alarming stories of Rwa lo tsā ba's adventures in Nepal and India and across the Tibetan heartland (Dbus and Gtsang), the myriad displays of his thaumaturgic powers, his wrathful acts of liberation, his inspired songs of realization (mgur), and his (tantric) dalliances with several young female consorts. But also of keen interest, for our purposes here, are the specific rituals and ritual techniques introduced in the biography that Rwa lo is said to have relied on to achieve his objectives. One such practice, appearing in several episodes, is called "Vajrabhairava's Four Syllables for Slaying and Repelling” (rdo rje 'jigs byed kyi yi ge bzhi pa'i gsad bzlog), which I shall come back to shortly. In addition to practices like this, which Rwa lo had received from his Nepali teachers, the biography is noteworthy, moreover, for its references to the numerous works of ritual instruction and tantric exegesis that Rwa lo is said to have written himself. In Tibet, these writings came to be known collectively as the Rwa pod (or poti), "The Book of Rwa.”

\section{The "Lost" Book of Rwa}

The Rwa pod, including the written texts of rites like the "Four Syllables for Slaying and Repelling" and works by the earliest authors of the Rwa tradition, has long been assumed by scholars to have disappeared in Tibet, forever lost to

\footnotetext{
9 Rwa Ye shes seng ge, Rwa lo rnam thar [=Mthu stobs dbang phyug rje btsun rwa lo tsā ba'i rnam par thar pa kun khyab snyan pa'i rnga sgra] (Xining: Mtsho sngon mi rigs dpe skrun khang, 1989); Ra Yeshé Sengé, The All-Pervading Melodious Drumbeat. For speculation on the possible date of the biography, see Cuevas, "Rva lo tsā ba and His Biographers," 71-76.

10 On Rwa Ye shes seng ge, see Cuevas, "Rva lo tsā $b a$ and His Biographers," 58-59 and sources cited therein.
} 
history, existing only as references and citations preserved in sources like the Rwa lo rnam thar, in several prominent Tibetan histories of the Vajrabhairava transmissions, and in a few traditional booklists. ${ }^{11}$ Recently, this situation has changed for the better.

In August 2018, I was excited to learn from Jann Ronis, executive director of the Buddhist Digital Resource Center (BDRC, formerly TBRC), that one of their field representatives in Mongolia, working with the Asia Classics Input Project (ACIP) at the National Library in Ulaanbaatar, had recently discovered and photographed what was believed to be four unique manuscript collections of the Rwa pod. The importance of the "discovery" of this long-absent anthology, in multiple versions no less, is not to be underestimated. ${ }^{12}$ In addition to the core writings and translations of Rwa lo tsā ba, these collections of manuscripts also contain works that have never before been available to modern scholars, including tantric commentaries, ritual manuals, and textual histories by important lineage figures such as Rwa Shes rab rgyal mtshan (fl. ca. 1250), a principal steward of the Rwa family practice and patriarch of the Eastern Rwa tradition ( $r w a$ shar lugs) who was the first to compile and propagate the Rwa pod; Rgya ston Kun dga' brtson 'grus (fl. ca. 1300), a prolific but relatively unknown Sa skya scholar named in some sources as Rwa lo tsā ba's fourth incarnation and the first to spread the Rwa transmissions to Khams in eastern Tibet and as far north as Tangut (Ch. Xixia); ${ }^{13}$ and 'Bri gung dpal 'dzin Nyi ma 'od zer dpal bzang po (fl. ca. 1350), the self-professed “Tibetan Śrīdhara” (bod kyi dpal 'dzin), disciple of

11 See, for example, the list reproduced in Lokesh Chandra, ed., Materials for a History of Tibetan Literature, (repr., Kyoto: Rinsen Book Co., [1963] 1981), 3:15 and 729-35 [863-70]. Chandra's list appears to be derived almost entirely from the seventeenth-century Thob yig of the Fifth Dalai Lama (Ngag dbang blo bzang rgya mtsho), Zab dang rgya che ba`i dam pa`i chos kyi thob yig gang ga'i chu rgyun, in Gsung 'bum (Dharamsala: Nam gsal sgron ma, 2007), 1:263.6-279.3.

12 In September 2018, I received the digital files of these manuscripts from the BDRC and began cataloging them in detail, cross-checking their contents against several reliable Tibetan booklists, especially the Fifth Dalai Lama's Thob yig and the histories of the Vajrabhairava cycle by 'Khon ston Dpal 'byor lhun grub (1561-1637), Tāranātha (1575-1634), and 'Jam mgon A myes zhabs (1597-1659), as well as the more recent inventories of the 'Bras spung libraries in Tibet, on which see 'Bras spungs dgon du bzhugs su gsol ba'i dpe rnying dkar chag, ed. Bstan 'dzin phun tshogs (Beijing: Mi rigs dpe skrun khang, 2004), 1:448-531, nos. 4700-5731. My publication of the completed catalogue is forthcoming.

13 Cuevas, "Rva lo tsā ba and His Biographers," 73-74. Rgya ston's father, Ru 'tshams Dbang phyug grags pa (sometimes Dbang phyug rgyal mtshan) was a direct disciple of Rwa Shes rab rgyal mtshan, from whom he received the Rwa transmissions. See, for example, the Fifth Dalai Lama, Zab dang rgya che ba'i dam pa’i chos kyi thob yig gang ga’i chu rgyun, 1:288.2, 288.5, 292.1-2, and 293.1. 
the Jo nang master Zhang ston Bsod nams grags pa (1292-1370). ${ }^{14}$ Incidentally, the collected writings of 'Bri gung dpal 'dzin on Vajrabhairava, which, like the Rwa pod, is referred to simply as Dpal pod or "The Book of Dpal," was also presumed to have been quite scarce until recently. ${ }^{15}$

\subsection{Manuscript Collection I: Rwa's Guiding Instructions (RP2)}

Three of the four Rwa pod versions acquired by the BDRC bear the catalog title Rwa khrid mkha' 'gro snyan brgyud ("Rwa's Guiding Instructions, Whispered Lineage of the dākinīs"), a title that is cited once in the Rwa lo rnam thar in reference to Rwa lo's special teachings and also in various traditional Tibetan bibliographies. ${ }^{16}$ The largest of these manuscript collections (W4CZ302660, henceforth abbreviated RP2) is in three volumes and comprises approximately

14 Alias Bdud sde rab tu 'joms pa 'bar ba'i gzhi brjid dpal bzang po. According to details recorded in the colophons, he was active in Gtsang rong and Mal gro, among other places, and was closely affiliated with the monastic centers of Mtshur phu, Shambhara, Thang skya, and Lhun grub rdzong. It should be noted, furthermore, that 'Bri gung dpal 'dzin is also the name of the obscure author of a controversial anti-Rnying ma polemical tract entitled Chos dang chos ma yin pa rnam par dbye ba’i bstan bcos (BDRC W1CZ885); for details see, most recently, Leonard van der Kuijp, "The Bird-Faced Monk and the Beginnings of the New Tantric Tradition, Part One," in Tibetan Genealogies: Studies in Memoriam of Guge Tsering Gyalpo (1961-2015), eds. Guntram Hazod and Shen Weirong (Beijing: China Tibetology Publishing House, 2018), 403-50 [446] and "The Bird-Faced Monk and the Beginnings of the New Tantric Tradition, Part Two,” Journal of Tibetology 19 (2018): 86-127 [97-100]. Whether these two authors are the same person remains a question for further study.

15 Contents of the Dpal pod are also listed in Chandra, Materials for a History of Tibetan Literature, 3:735-38 [870-73], again derived from the Fifth Dalai Lama's Thob yig. See Fifth Dalai Lama, Zab dang rgya che ba'i dam pa’i chos kyi thob yig gang ga’i chu rgyun, 1:279. 3-284.3. Photographic images of a separate (incomplete) manuscript version of the Dpal pod in cursive script ( $\mathrm{dbu}$ med) of uncertain origin have recently been made available (under restricted circulation) by the BDRC, registered with the title Rdo rje 'jigs byed kyi man ngag gi chos skor (W3CN2615).

16 Rwa Ye shes seng ge, Rwa lo rnam thar, 235; Ra Yeshé Sengé, The All-Pervading Melodious Drumbeat, 214. Interestingly, 'Jam mgon A myes zhabs indicates that this title, Rwa khrid mkha' 'gro snyan brgyud, is actually a well-known name for the specific Rwa lineage issuing from the sixteenth-century Sa skya master Tshar chen Blo gsal rgya mtsho (1502-67), a leading promoter of the Eastern Rwa tradition. See 'Jam mgon A myes zhabs Ngag dbang kun dga' bsod nams, Dpal gshin rje'i gshed skor gyi dam pa'i chos byung ba'i tshul legs par bshad pa 'jam dpal chos kun gsal ba’i nyin byed, in Collected Works (Kathmandu: Sa skya rgyal yongs gsung rab slob gnyer khang, 2000), 15:231. 
168 individually titled manuscripts copied on 1,344 leaves in a clear "headed" script ( $d b u$ can). The first volume opens with forty-nine works attributed to 'Bri gung dpal 'dzin (i.e. the Dpal pod), which in all probability were composed between the years 1384 and $1397 .^{17}$ The remainder of the volume contains all the standard texts of the Rwa pod with a few additions. The second volume is made up of mostly duplicate titles written in different hands from those in the first volume and display other markers indicating the texts belong to at least two separate and unique Rwa pod witnesses. These are unidentified in the BDRC records, but should be distinguished from RP2 and assigned their own catalog numbers. The third volume is comprised of only a single manuscript documenting a specific lineage of the reading transmission (lung) of the Rwa pod, which passed directly through the famous Amdo scholar A khu ching Shes rab rgya mtsho (1803-75), one of Tibet's great antiquarians. ${ }^{18}$ All the manuscripts in RP2

17 The Tibetan years listed in the colophons are shing pho byi (=1384?), shing pho khyi (=1394?), me pho byi (=1396?), and me mo glang (=1397?). The colophons also record that a number of these texts were composed at the request of two individuals: a monk named Kun dga' dbang phyug (who also appears to have served as scribe) and a disciple named Rtogs ldan Bsod nams dpal from Mdo khams. I have yet to identify them in the available lineage records. The BDRC, without citing its source, identifies this Kun dga' dbang phyug as the Fourth Ngor chen Kun dga' dbang phyug (1424-78; see records P4CZ75592 and P1040), but his floruit does not correlate well to the plausible dates of 'Bri gung dpal 'dzin in the mid-fourteenth century. The latter must have been mature and active at least a decade or more before 1370, the year his principal teacher died, Zhang ston Bsod nams grags pa. If, however, we were to assume the BDRC's identification to be correct, and adjust the composition years one $r a b$ 'byung cycle forward to 1444-57, we would then be left with the unrealistic possibility of 'Bri gung dpal 'dzin composing these texts at the ripe old age of 100 , or even older!

18 The title of this work in six folios is Yi dam rdo rje 'jigs byed kyi chos skor rwa pod du grags pa'i lung thob pa'i brgyud thob bzhugs so (RP2, 3.001). A khu ching's name appears in the lineage handwritten in cursive and marked by a swastika at the end of the manuscript. After him, the list continues with Mkhan chen Ngag dbang thub bstan rgya mtsho (1836-89), Rje dam pa Bsam gtan rgya mtsho, Sngags rams pa Blo bzang dge 'dun dpal bzang po, and one selfidentified as Blo ring, the supposed author of the text. As for who this Blo ring is, I can only speculate that he was likely affiliated with Bla brang bkra shis 'khyil, Sku 'bum, or both in the late nineteenth century. Blo ring is an obvious abbreviation, but I have not found any names at these institutions from the period that would suitably fit. One other potentially fruitful lead: the text mentions the gsan tho ("list [of teachings] received") of Rgyal ba Blo bzang skal bzang rgya mtsho, whom I identify as the Fourth Gro tshang brag (b. 1876). He became abbot of Sku 'bum in 1899 (tenure 1899-1901). For a brief summary of his career, see Joachim Günter Karsten, “A Study of the Sku-'bum/T'a-erh ssu Monastery in Ch'ing-hai” (PhD diss., University of Auckland, 1996), 471-73. 
appear to be based on both Sa skya and Dge lugs transmissions and some texts, particularly in the last two volumes, may be traced back to Bla brang Bkra shis 'khyil or Sku 'bum monasteries in Amdo, probably early 1900s. ${ }^{19}$

\subsection{Manuscript Collections II and III: Rwa's Guiding Instructions (RP3 and RP4)}

The second and third BDRC versions of the Rwa pod registered by the title Rwa khrid mkha' 'gro snyan brgyud (W4CZ58529, henceforth RP3, and W8LS29654, RP4, respectively) are mostly identical. They comprise the same core content in two volumes, with 59 individually titled manuscripts copied on 346 leaves in a fine cursive calligraphy ( $d b u$ med). By style, at least, these appear rather old, perhaps from the seventeenth or eighteenth century. Different scribal hands are evident throughout the collection. Of particular note in the beginning of the first volume of RP3 is the language of its dkar chag ("list of contents"), which matches almost verbatim the Thob yig ("Record [of Teachings] Received") of the Fifth Dalai Lama (1617-82). Also, on a few of the manuscript folios are written interlinear annotations (mchan bu) that cite the Fifth Dalai Lama explicitly by name. Thus, I suspect the compiler or editor of this collection used the Fifth Dalai Lama's booklist as a guide for identifying and arranging the texts. Given that the Thob yig was written between 1665 and 1670, we can be assured that these manuscripts could not have been produced before the 1670s. As for RP4, on closer inspection, its first volume is a duplicate of RP3; the manuscript pages are identical, except that the digital files in RP4 are collated in a different order. Moreover, many of its scanned folios are mixed up between individual manuscripts, in disarray, or missing altogether. The second volume of RP4 contains ten unique b/w photocopied manuscripts in 161 folios arranged four folios per page. These comprise liturgical writings on Vajrabhairava, following the Rwa tradition, by Ngor chen Dkon mchog lhun grub (1497-1557), originally composed at Ngor evam chos ldan in 1547. The provenance of these manuscripts is unknown. In the end, unfortunately, the version of the Rwa pod represented here in RP3/ RP4 is incomplete, missing several of the core works.

19 See previous note. 


\subsection{Manuscript Collection IV: The "Faded Document" (RP1)}

The fourth manuscript version of the Rwa pod (W8LS32375, henceforth RP1) is a single volume of 155 leaves containing 79 texts arranged continuously with no separate title pages and largely copied by a single distinctive hand in mostly legible $d b u$ can script (abundant ink stains throughout the collection render many lines difficult to decipher). This version forms a complete and coherent "book." Moreover, in comparison with the other manuscript collections, this one most closely matches the content and ordering of the thirteenth-century dkar chag of Rwa Shes rab rgyal mtshan, which is included in the collection as text no. 002 (described below). Consequently, I have tentatively classified this manuscript as the "master version," since it very likely approximates the Rwa pod in its original form. In this regard, it is worth mentioning that many of its texts conclude with a proofreader's notation (indicated by some variation of the phrase ma dpe ltar gcig zhus dags) confirming that the present copy matches an exemplar ( $m a$ dpe) that we do not have. That this exemplar could have been very old remains a possibility, but unless or until such an earlier witness becomes available, we cannot be certain. Regrettably, the extant manuscript materials do not allow any conclusive statement on this matter, though it may be significant that the volume as a whole very likely derives from the Ngor branch of the Sa skya tradition.

The library title given to this master version of the Rwa pod is borrowed from the first text that appears in its volume: Rdo rje 'jigs byed kyi rwa'i thim yig rwa los mdzad pa ("Rwa's Faded Document on Vajrabhairava Produced by Rwa lo"). This peculiar one-folio "Faded Document" or Thim yig - more frequently cited in later sources as Dkar chag tshigs bcad ma ("Verse Catalog") - presents an index of the titles of Rwa lo tsā ba's original compositions written in narrative verse. ${ }^{20}$ The work, as its former title makes clear, is claimed to have been written by Rwa lo himself, and thus in the table of contents reproduced therein, we find the core structure of the Rwa pod as it must have initially been conceived. ${ }^{21}$ That core structure consists of the following sixteen integrated works attributed to Rwa lo

20 Versions of the Thim yig are found in RP1 (001), 1-2r2; RP2 (1.002 and 2.009); and RP3 (1.002). Its colophon specifies that the document was composed by Rwa lo tsā ba himself and that (later?) it was copied from the dictation of a certain Rje btsun Kun dga', who may very well have been Rgya ston Kun dga' brtson 'grus. The Tibetan reads: ces lo tstsha ba rdo rje grags rang nyid kyis thim yig bkod pa'o / bcu drug gi grangs 'di rje btsun kun dga'i zhal las bris so.

21 Virtually the same title list is reproduced in Rwa Ye shes seng ge, Rwa lo rnam thar, 222-23; Ra Yeshé Sengé, The All-Pervading Melodious Drumbeat, 201-2. 
tsā ba and based on his translation of the Śri-Vajramahābhairava-tantra (Tib. Dpal rdo rje 'jigs byed chen po'i rgyud, Derge 468), the root tantra of the Vajrabhairava cycle in seven chapters (Rgyud kyi rgyal po rtog bdun). ${ }^{22}$ Versions of all the numbered texts listed here are found in the RP1 manuscript:

[1] Nag 'grel ("Black Commentary") $)^{23}$

[2] Dkar 'grel ("White Commenary") ${ }^{24}$

[3] Bcud thigs ("Elixir Drop") 25

[4] Gsod pa’i mtshon ("Killing Weapon”) or Ha la nag po’i shog dril gsum ("Three Scrolls of Ha la nag po") ${ }^{26}$

- Khar rgyud yi ger ma bkod ("Verbal Transmissions Not Recorded in Writing”)

[5] Bsnyen sgrub dgra srog dbang bsdud ("Ritual Approach and Evocation Subjugating the Life-Force of Enemies") $)^{27}$

- Mngon rtogs rim pa lnga ("Fivefold Manifest Realization" =sādhana, listed as follows:)

[6] Yid bzhin gter mdzod ("Wish-Fulfilling Treasury") [=sādhana for the thirteen deities] $]^{28}$

[7] Dri med snang ba ("Stainless Illumination") [=sādhana for the solitary deity $]^{29}$

[8] Khams gsum za byed ("Devourer of the Three Worlds") [=sādhana for the three-faced six-armed deity] $]^{30}$

22 English translation in Siklós, The Vajrabhairava Tantras, 27-49.

23 RP1 (010), Rtog pa bdun pa'i nag 'grel rdo rje 'jigs byed kyi tshig don rnam bshad, 44r7-57r6; cf. RP2 (1.058 and 2.014); missing in RP3/RP4.

24 RP1 (011), Dpal rdo rje 'jigs byed kyi rgyud kyi dkar 'grel pa, 57r7-77r4; cf. RP2 (1.059 and 2.013) and RP3 (1.012).

25 RP1 (012), Bcud kyi thigs pa, 77r5-82v6; cf. RP2 (1.060, 2.001, and 2.023) and RP3 (1.013).

26 RP1 (013-015), De’i gsung ha la’i shog dril dang po'i rtsa ba, Shog dril gnyis pa’i rtsa ba, Shog dril gsum pa’i rtsa ba, 82v6-84v3; cf. RP2 (1.082, 1.085b, 1.085c, 1.100, and 2.048) and RP3 (1.014). Ha la nag po is an esoteric form of Avalokiteśvara (Skt. Hālāhala). The term also refers to a lethal poison.

27 RP1 (016), Rtog pa bdun pa'i dka' 'grel [bsnyen sgrub dgra srog dbang sdud kyang zer], 84v3-92r2; cf. RP2 (1.061, 1.062, 1.078, 2.002, and 2.066); missing in RP3/RP4.

28 RP1 (017), Dpal rdo rje 'jigs byed kyi mngon par rtogs pa yid bzhin gyi gter mdzod, 92r2-105r7; cf. RP2 (1.063 and 2.008) and RP3 (1.015).

29 RP1 (018), Gtso bo'i bsgrub thabs dri med snang ba zhes bya ba rwa lo tstsha ba rdo rje grags pas mdzad pa, 105r7-109r5; cf. RP2 (1.064 and 2.003) and RP3 (1.016).

30 RP1 (019), Rdo rje 'jigs byed zhal gsum phyag drug pa'i mngon rtogs khams gsum za byed, 109r5-110v4; cf. RP2 (1.065 and 2.004) and RP3 (1.017). 
[9] Dri med chu rgyun ("Pure Flowing River") [=sādhana for the one-faced four-armed deity $]^{31}$

[10] Rin chen don bsdus ("Precious Synopsis") [=sādhana for the one-faced two-armed deity $]^{32}$

- Las bzhi'i sbyin sreg cho ga ("Burnt Offering Rites for the Four Actions" =homa, listed as follows:)

[11] Mi mthun kun sel ("Elimination of All Discordances") [=homa for pacification] $]^{33}$

[12] 'Dod pa kun 'phel ("Proliferation of All That Is Desired") [=homa for enrichment] ${ }^{34}$

[13] Gnad kyi lcags kyu (“Crucial Iron Hook”) [=homa for subjugation] ${ }^{35}$

[14] Dgra bgegs kun 'dul ("Vanquishing All Enemies and Obstructors") [=homa for fierce assault $]^{36}$

[15] Smin byed dkyil chog ("Ripening Empowerments and maṇdala Rites") or Dbang chu chen mo ("Vast River of Initiations") ${ }^{37}$

[16] Dmar po mda' bzhu 'gengs pa ("Drawing Back the Red One's Bow and Arrow") or Dug dbang rma bya rgyas pa ("Elaborate Poison-Powered Peacock") $)^{38}$

31 RP1 (020), Rdo rje 'jigs byed zhal gcig phyag gzhi pa'i mngon rtogs dri med chu rgyun zhes bya ba rwa los mdzad pa, 110v4-112r3; cf. RP2 (1.066 and 2.005) and RP3 (1.018).

32 RP1 (021), Rdo rje 'jigs byed zhal gcig phyag gnyis pa'i mngon rtogs rin chen don 'dus, 112r3-113r7; cf. RP2 (1.067, 1.101, 2.006, and 2.049) and RP3 (1.019)

33 RP1 (022), Rdo rje 'jigs byed kyi las bzhi'i sbyin sreg bzhugs so [zhi ba'i sbyin sreg mi mthun kun sel], 113r7-114r2; cf. RP2 (1.068 and 2.007); missing in RP3/RP4.

34 RP1 (023), Rdo rje 'jigs byed kyi rgyas pa'i sbyin sreg 'dod pa kun 'phel, 114r2-6; cf. RP2 (1.068 and 2.007); missing in RP3/RP4.

35 RP1 (024), Rdo rje 'jigs byed kyis sbyin sreg gnad kyis lcags kyu, 114r6-114v4; cf. RP2 (1.068 and 2.007); missing in RP3/RP4.

36 RP1 (025), Rdo rje 'jigs byed kyi drag po'i sbyin sreg gi cho ga cha lags dang bcas pa, 114v4-121r6; cf. RP2 (1.068 and 2.007); missing in RP3/RP4.

37 RP1 (030), Dpal rdo rje 'jigs byed kyi dbang ki chu bo, 142v2-167v5; cf. RP2 (1.072 and 2.018) and RP3 (1.022).

38 RP1 (026-027), Dpal rdo rje 'jigs byed chen po'i dug dbang rma bya rgyas pa'i chos skor zab cing cha tshing ba gcig, 121r7-140r2 and Dmar po mda' gzhu 'gengs pa'i dbang sdud, 140r2-5; cf. RP2 (1.069, 1.070, 2.015, and 2.016) and RP3 (1.020). Immediately following these in RP1 are two other short texts that may also turn out to be a part of this larger cycle; see RP1 (028-029), 'Jigs byed dmar po zhal gcig phyag gnyis bsgom thabs, 140r6-142r3 and Nag po mda' gzhu 'gengs pa'i sngags, 142r6-142v1. A more thorough inspection of the contents of these texts should help to clarify the specific relationships between them. Note that Tāranātha is skeptical that the Dmar po mda' gzhu 'gengs pa was actually composed by Rwa lo tsā ba, suggesting instead that it evolved from the oral tradition and was only later preserved in writing. See Tāranātha, Rgyud rgyal gshin rje gshed skor gyi chos 'byung rgyas pa yid ches ngo mtshar, in 


\subsection{The Expanded Catalog of Rwa Shes rab rgyal mtshan}

This core listing in the Thim yig was elaborated (rgyas bshad) by Rwa Shes rab rgyal mtshan to include a much more complete range of Rwa lo tsā ba's writings and translations, incorporating also some of Rwa lo's purportedly autobiographical notes and recollections, again written all in narrative verse. This extended catalog is variously titled Rwa lugs kyi gshin rje gshed nag po'i rgya bod kyi yig cha'i dkar chag ("Catalog of the Indian and Tibetan Books on Kṛ̣nayamāri of the Rwa Tradition”), or often simply Dkar chag tshigs bcad ma'i 'grel ba ("Commentary to the Verse Catalog"), and appears as the second text in manuscript RP1. ${ }^{39}$ Its colophon records that the catalog was compiled and preserved in writing at a monastery called Ga gon [gong] dpal, presumably in central Tibet. The Dkar chag is divided into six sections:

(1) Rwa lo tsā ba's translations of the Indian works on Kṛ̣̣nayamāri ('jam dpal nag po'i rgya ba gzhung) - these include the root tantra, its commentaries, and ritual practices by Śrīdhara (ca. 950-1050) ${ }^{40}$ and Buddhaśrījñāna (ca. 750-830), ${ }^{41}$ and Rwa lo's revisions of previous translations by Tibetans Nag tsho lo tsā ba (1011-64) and Zangs dkar lo tsā ba (1012-97), among others.

(2) Rwa lo tsā ba's writings he produced himself (bdag nyid kyi mdzad pa'i yi ge yod tshul) - these are mainly Rwa lo's ritual manuals based on the works of Śrīdhara and his own notes on esoteric instructions he received personally from Guru Bha ro dealing with a variety of magical procedures, which are divided here into two collections:

(a) Sixteen writings labeled Zin bris chen mo ("Substantial Notes") - these include instructions on procuring the medicinal eye ointment (mig sman),

Collected Works by Jonang Master Jetsun Täranātha (Beijing: Krung go’i bod rig pa dpe skrun khang, 2008), 11:132-33.

39 RP1 (002), 2r2-6r1; RP2 (1.049 and 2.011); RP3 (1.003 and 1.024). Citations of the Dkar chag are found in several Tibetan histories of the Rwa transmissions, but Tāranātha, characteristically, is the only one among them who offers his own critical analysis and commentary. See Tāranātha, Rgyud rgyal gshin rje gshed skor gyi chos 'byung, 128-35.

40 On Śrīdhara, see Kuranishi Kenichi, "Śrīdhara and His Works on the Yamāri Cycle," in Esoteric Buddhist Studies: Identity in Diversity Proceedings of the International Conference on Esoteric Buddhist Studies, Koyasan University, 5 Sept.-8 Sept. 2006 (Japan: Koyasan University, 2008), 179-83.

41 Alias Buddhajñānapāda (Tib. Sangs rgyas ye shes zhabs), preceptor of the Pāla emperor Dharmapāla (r. ca. 775-812). See Alexis Sanderson, "The Śaiva Age: The Rise and Dominance of Śaivism during the Early Medieval Period," in Genesis and Development of Tantrism, ed. Shingo Einoo (Tokyo: Institute of Oriental Culture, University of Tokyo, 2009), 93-94. 
methods for deploying the magic wheel devices ('khrul 'khor, Skt. yantra), ${ }^{42}$ measures for embracing and dividing (kha sbyor dbye ba), uncommon explanations on the "sixty-four" [gtor ma] (drug bcu rtsa bzhi pa), ${ }^{43} \mathrm{a}$ system for directing the mind toward awakening in the intermediate state (bar do’i byang chub sems), as well as such mysterious teachings as "Legend of the Fool of Magadha" (ma ga ta'i glen pa'i gtam rgyud), "Heruka's Grand Exegesis" (he ru ka'i mam bshad chen mo), and the like.

(b) Twenty-five writings titled Las 'phrad ['phrod] zab mo ("Profound Compilation of Ritual Actions”) - these include rites for decidedly more mundane purposes, for example, procedures for making rain, causing leprosy, curing snakebite, relief from headaches, stopping floodwaters, animating corpses (ro langs, Skt. vetāla), achieving swiftfootedness and invisibility, subjugating demons, invoking the children of devas and nāgas, and so on.

(3) Texts not included in the catalog of Rwa lo tsā ba's writings (bla ma’i gsung gi dkar chag na mi bzhugs) - these are briefly the writings of Rwa lo's family members who served also as his chief lineage holders, namely, nephew Rwa Chos rab and Chos rab's two sons, Rwa Ye shes seng ge and Rwa Dharma seng ge, as well as texts related to Six-Faced Yamāntaka (Ṣaṇmukha, Tib. Gdong drug). ${ }^{44}$

(4) Rwa lo tsā ba's translations of the Indian works on Vajrabhairava (rdo rje 'jigs byed kyi bzhung) - these include the root tantra, its commentaries, and ritual practices (e.g. sādhana, maṇdala, homa, yantra, etc.) attributed to Śrībhadra, Amoghavajra, Dīpaṃkara, Ratnākaraśānti, and Guru Bha ro.

42 For a brief discussion of yantra rites in the tantras of Yamāri/Yamāntaka, especially Kṛ̣ṇayamāri, see Kuranishi Kenichi, "Yantras in the Buddhist Tantras - Yamāritantras and Related Literature," in Puspikā: Tracing Ancient India through Texts and Traditions. Contributions to Current Research in Indology, vol. 1, Proceedings of the First International Indology Graduate Research Symposium (September 2009, Oxford), eds. Nina Mirnig, Péter-Dániel Szántó, and Michael Williams (Oxford: Oxbow Books, 2013), 265-81.

43 A special offering to the protector of the Vajrabhairava tantras, the fearsome Karmayama (Tib. Las kyi gshin rje), aliases Dharmarāja and Kālarūpa.

44 Tāranātha is critical of Rwa Shes rab rgyal mtshan in this section, specifically the latter's claim that Rwa Chos rab had never composed any of his own writings. Tāranātha argues, on the contrary, that Rwa lo tsā ba's nephew had apparently written a text (yig sna) on the ritual approach and evocation of Kṛṣnayamāri (Nag po’i bsnyen sgrub las gsum =Śāntijñāna’s Bsnyen sgrub las gsum kar ston pa'i sgrub thabs?) and that Rwa Ye shes seng ge and his son 'Bum seng ge later expanded the text a little bit. See Tāranātha, Rgyud rgyal gshin rje gshed skor gyi chos 'byung, 131 (and 126 on Śāntijñāna's work). 
(5) Rwa lo tsā ba's Tibetan works on Vajrabhairava (bod kyi yi ge yod tshul) these are the sixteen texts listed in the Thim yig.

(6) Rwa lo tsā ba's writings on Vajrabhairava in his own words (bla ma'i zhal nas rdo rje 'jigs byed) - this is a duplication of the Thim yig in full with a variant rendering of its concluding verses.

On examining the various Rwa pod collections recently acquired by the BDRC, it is evident that some effort was made to organize the manuscripts on the basis of these two formative catalogs - Rwa lo tsā ba's own index, the Thim yig, and its subsequent expansion by Rwa Shes rab rgyal mtshan. As would be expected, both texts are typically placed first in these collections.

\section{4 "Vajrabhairava's Four Syllables for Slaying and Repelling"}

Having now briefly introduced the Rwa pod and its various extant manuscript versions, it would be worthwhile to highlight one short but particularly illustrative example of the type of work that one finds in these newfound writings of Rwa lo tsā ba and associated texts by the earliest propagators of his tradition - I refer again to the aforementioned "Four Syllables for Slaying and Repelling." This intriguing document is not only available in two versions of the Rwa pod (Figs. 1 and 2) and in another independent witness (Fig. 3 ), ${ }^{45}$ but it also features in two

45 RP1 (053), Yi ge bzhi ba'i bsad bzlog, 266v4-267v1; RP2 (1.086); missing in RP3/RP4. The independent version, titled Rwa lo'i bzlog pa bsam gtan nyal chog, is the opening text of a larger compilation in eleven folios containing two or more additional Vajrabhairava rituals of a similar type (see BDRC W1CZ1303, henceforth RCN). The text of the "Four Syllables" in this manuscript concludes with the following short transmission lineage (fol. 3v2-3): Rgya [ston?] rin po che [break?] Dpal ldan grags pa, Rje btsun dam pa Nam mkha' lhun grub bzang po [=Jo gdan Nam mkha' lhun bzang?], "me” [b]tsun pa Bkra shis rin chen [=teacher of Ngor chen Kun dga' bzang po (1382-1456)?]. A second lineage transmitted through Khro phu ba [=Khro phu lo tsā ba (ca. 1172-1236)] is given in the next section of the manuscript (fol. 3v6): Khro phu ba, Rgya ston dbang phyug rgyal mtshan, Rgya ston Kun dga' brtson 'grus, Chos kyi grags pa. This is the transmission line for a practice associated with the esoteric instructions (man ngag) of Ba ri ba [=Ba ri lo tsā ba?] described as phyir bzlog 'khor lo / byad ma bsod pa'i lag cha / bon po'i gshed ma shes cho ga'i man ngag zab mo mthar thug pa.

I should mention also the existence of a slightly longer variation of the "Four Syllables" that is markedly different from the three versions examined here. This extended version in three folios is included in the be'u bum ("handbook of magical rites") of 'Jam dbyangs mkhyen brtse'i dbang po (1820-92), compiled in the late nineteenth century, and bears the title Gshin 
prominent episodes in the Rwa lo rnam thar. With this brief example, I hope as well to draw attention to the threads that inextricably tie a tantric tradition's rituals to its stories, and vice versa, passed down through the ages from one generation to another.

\subsection{Story of the "Four Syllables"}

In the Rwa lo rnam thar, we read of numerous conflicts and magical battles that Rwa lo tsā ba wins through Vajrabhairava sorcery. Two of these episodes are worth noting for reference to the practice of the "Four Syllables for Slaying and Repelling," versions of which are now accessible in the Rwa pod and translated in appendix 1.

\subsubsection{Contest with a Vajrakīla Master}

The first episode involves a prominent Tibetan master of the Buddhist wrathful deity Vajrakīla named Lang lab Byang chub rdo rje. In Rwa lo's initial contest with Lang lab, the Vajrakila master succeeds in magically defeating him. Stunned by this unexpected outcome, and prompted by a vision of the goddess Tārā, Rwa lo returns to Nepal to receive further instructions from his teacher, Guru Bha ro. The biography then describes the following:

From there Rwa lo and the rest went to Nyi ma steng monastery and met with Master Bha ro. Rwa lo offered eight ounces of gold as a gift to him, and Bha ro was extremely pleased. He said to Rwa lo, "It is good that you've come to dispel doubts about the Dharma. Prepare a communal feast (tshogs 'khor, Skt. ganacakra) and I'll give you the instructions.” Then, after Rwa lo related the story of Lang lap and how much he detested him, Bha ro added, "I have the instruction called 'Slaying and Repelling with the Four Syllables of Vajrabhairava' that is most effective for rendering you invincible against a whirlwind of ritual attacks, no matter what they are, even the sorcery, spell casting, and

rje yi ge gzhi pa’i srung bzlog bsad pa’i man ngag rdo rje pha lam ("Esoteric Diamond Instructions on Yama's Four Syllables for Slaying and Repelling”). The colophon indicates that the text was granted in secrecy to Rwa lo tsā ba by the Nepali Mahākarunika upon being offered one hundred (!) ounces of gold (rather than the mere eight ounces noted in all the other versions). The Tibetan reads: gshin rje yi ge bzhi pa’i srung bzlog bsad pa’i man ngag zhal shes dang bcas pa rwa lo tsā ba rdo rje grags kyis bal po thugs rje chen po la gser srang brgya 'bul bar dam bcas nas gnang ba'i gdams pa chig brgyud shin tu zab mo. See 'Jam dbyangs mkhyen brtse'i dbang po, Man ngag gces btus sna tshogs phyogs gcig tu bsgrigs pa 'dod rgu kun 'byung dbang rgyal nor bu'i phreng ba, in The Collected Works (Gsung 'bum) of the Great 'Jamdbyañs Mkhyen-brtse'i-dbari-po (Gangtok: Gonpo Tseten, 1977-1980), 20:532.5-537.1. 
counterspells of a hundred thousand Buddhist, Bon po, and Hindu ( $m u$ stegs, Skt. tirthika) tantric priests. In addition to that, I have a further series of instructions for defense, repelling, slaying, and suppressing, and many ritual applications (las tshogs) for pacifying, increasing, and controlling, as well as the oral instructions on the eight dharmas of necessity (dgos pa'i chos brgyad) and the three cherished essentials (gces pa rnam gsum). Since I have so many of these sorts of marvelous instructions, I shall give them all to you. ${ }^{46}$

The episode concludes with Rwa lo returning to Tibet and engaging Lang lab in a second round of magical combat, only this time it is Lang lab who succumbs to Rwa lo's Vajrabhairava powers, driven by the "Four Syllables" in particular. Lang lab is then said to have grown ill with a bloody pox (dmar shal gyi rims kyis bsnyun) and to have died soon thereafter. ${ }^{47}$

As we see in appendixes 1 and 2, the manuscript versions of this harmful rite from the Rwa pod open similarly to the scene quoted above: Rwa lo offers his teacher eight ounces of gold for further instructions on Vajrabhairava, which he receives in the form of the "Four Syllables." We should note, however, a discrepancy in the name of Rwa lo's Nepali teacher: the ritual text identifies him as Guru Mahākarunika (Tib. Thugs rje chen po) rather than Guru Bha ro, as he is named in the Rwa lo rnam thar. Earlier I had mentioned that this confusion over the identity of Rwa lo's mentor(s) was common among the early biographers and historians of the Rwa tradition. Rgya ston Kun dga' btson 'grus, for example, failed to differentiate the names Bal po Thugs rje chen po, Mahākanika [Mahākarunika], Dīpamkara, Bha ro phyag rdum, and Mi dza gling pa in his Lo rgyus gyi yig gi don gsum pa ("Three-Part Historical Document"), alternatively titled Dpal rdo rje 'jigs byed kyi rgyud dang bla ma brgyud pa'i byon tshul ("History of the Glorious Vajrabhairava Tantra and Its Lineage of Teachers”) - the earliest known history

46 Ra Yeshé Sengé, The All-Pervading Melodious Drumbeat, 56-57 (modified for consistency of style); Rwa Ye shes seng ge, Rwa lo mam thar, 60-61: de nas nyi ma steng dgon par byon / slob dpon bha ro dang mjal te gser srang brgyad phyag rten du phul bas / bha ro yang shin tu dgyes par gyur te / khyod chos kyi sgro 'dogs bcad du 'ongs pa legs tshogs 'khor bshoms shig gdams pa bya yi gsungs / der lang lab dang 'gras pa'i lo rgyus zhus pas / nga la dpal rdo rje 'jigs byed kyi yi ge bzhi pa'i gsad bzlog ces bya ba ban bon sngags pa mu stegs 'bum gyi mthu gtad sel gsum 'go chog rlung 'khor gang gis kyang mi tshugs pa gcig yod / gzhan yang bsrung bzlog gsad man mnan gyi rim pa dang / zhi rgyas dbang gsum gyi las tshogs mang po dang / dgos pa'i brgyad dang gces pa rnam gsum la sogs pa’i gdams ngag ngo mtshar can mang du yod kyis khrod la sbyin no gsungs.

47 Rwa Ye shes seng ge, Rwa lo rnam thar, 88; Ra Yeshé Sengé, The All-Pervading Melodious Drumbeat, 81. 
of the Vajrabhairava cycle extant in two of the Rwa pod collections. ${ }^{48}$ Part of the confusion seemed to be due to the fact that both of Rwa lo's teachers were from Nepal (Bal po in Tibetan) and held the aristocratic title "Bha ro," used commonly in post-eleventh-century Nepal for persons of high standing. ${ }^{49}$ Moreover, both shared a similar alias, Dīpaṃkaraśrī (Bha ro phyag rdum) and Dīpaṃkararakșita (Mahākarunika). The mistake appears to have persisted into the seventeenth century before certain astute historians of that period, such as Tāranātha and the Fifth Dalai Lama, were able to correct the record. ${ }^{50}$ That the ritual text of the "Four Syllables" displays this conflation of identities should give us a clue as to the text's early date and possible authorship.

\subsubsection{Contest with Three Hayagrīva Yogins}

In a second episode much later in the biography, Rwa lo is challenged by three yogins - 'Bre Shes rab bla ma, Sum pa Dbang tshul, and Rkyang po Grags pa byang chub - who had just earlier uncovered as treasure (gter ma) a tantric cycle of Hayagriva from the region of Yer pa in central Tibet. ${ }^{51}$ Rwa lo was

48 RP1 (034), Dpal rdo rje 'jigs byed kyi rgyud dang bla ma brgyud pa'i byon tshul, 183v2-187v5; RP2 (1.076 and 2.021); missing in RP3/RP4. Rgya ston is explicit about the identifications: de slob ma bal thugs rje chen po / mtshan gyi rnam grangs la / mahā ka ni ka dang / di pam ka ra dang / bha ro phyag bsdum [=rdum] dang / mi dza gling pa zhes pa rnams so / de yang mu stegs kyi pandi ta yin te. See RP1, 186v5; cf. also RP2 (1.076), 5v3-4 and RP2 (2.021), 4v5.

49 On this status designation in Nepal, see Ronald M. Davidson, Tibetan Renaissance: Tantric Buddhism in the Rebirth of Tibetan Culture (New York: Columbia University Press, 2005), 135.

50 References in Cuevas, "Rva lo tsā ba and His Biographers," 64, note 41.

51 The first yogin is 'Bre Shes rab 'bar, a student of Rngog Blo ldan shes rab (1059-1109). He appears again at various points in the biography, and in other lineage records, as a devout and influential Bka' gdams pa disciple of Rwa lo tsā ba. Sum pa Dbang tshul is known to have been a disciple of Zur chen Śākya 'byung gnas (1002-62). Rkyang po Grags pa byang chub is a minor “treasurer-revealer" (gter ston) mentioned in 'Jam mgon Kong sprul's (1813-1900) Gter ston brgya rtsa'i mam thar [=Zab mo'i gter dang gter ston grub thob ji ltar byon pa'i lo rgyus mdor bsdus bkod pa rin chen vaidūrya'i phreng ba], in Rin chen gter mdzod chen mo (New Delhi: Shechen Publications, 2007-16), 1:534-36. Here, in fact, Kong sprul gives a variant account of this very same story of the three Hayagriva yogins in reference specifically to the later gter ma revelations of 'Dar phyar ru pa (namely, the Rta mgrin padma dbang chen yang gsang khros pa cycle), but with no mention at all of Rwa lo tsā ba. The story is probably an old legend that was passed down with the Hayagriva teachings and inserted at some point into the biographical traditions of Rwa lo tsā ba and perhaps also of 'Dar phyar ru pa. My thanks to José Cabezón for helping me to clarify my thoughts about the possible origins of this story, which I had initially assumed (incorrectly) to have been connected to the charter myth of a famous 
unimpressed by their miraculous demonstrations and left them for the nearby district of Snye thang to tour the sacred sites associated with Atiśa (980-1054). As Rwa lo was there making his pilgrimage rounds, the following occurred:

Meanwhile, 'Bre Shes rab bla ma, Sum pa Dbang tshul, and Rkyang po Grags pa byang chub, the three of them, had grown envious of Rwa lo and performed elaborate rites of sorcery ( $m$ thu rgyas byas) against him. 'Bre performed a burnt offering (sbyin bsreg, Skt. homa), Sum pa hurled sacrificial cakes (gtor ma, Skt. bali), while Rkyang po cast a curse (gtad rgyab) and sent the Bla ma [Rwa lo] frightening apparitions (cho 'phrul, Skt. prātihārya). In response, the Bla ma meditatively cultivated the practice of "Slaying and Repelling with the Four Syllables," which foiled their sorcery. It is said that 'Bre went insane, Sum pa died, and Rkyang po was infected with leprosy. What happened to these three was kept secret by their followers. ${ }^{52}$

Here in this account of magical assault we see again the fearsome power of the "Four Syllables," capable of effecting the most destructive of outcomes, truly a "most profound dark counteracting force" (yang gsang mthu bzlog nag po) as the text of the ritual itself describes it. On first reading, Rwa lo's fierce reaction to his three antagonists seems to be justified by some unspoken ethics of retribution, a sort of "eye for an eye" in Tibetan ritual code. But more likely, in the end, at least for Rwa lo's faithful supporters, his deeds must be viewed as founded on the principle of compassionate violence so emblematic of the Buddhist tantras. It is hardly surprising then that Rwa lo tsā ba was such an ambivalent sensation in Tibet, straddling as he did the dagger's edge separating the justifiable acts of a benevolent and wise but formidable bodhisattva from the condemnable abuses of a murderous villain.

There are other similarly powerful rites recounted in the Rwa lo rnam thar that are now also available in the recently acquired Rwa pod collections; notable among them, the Ușnișa'i bzlog pa zab mo ("Profound Repelling Rite of [Wrathful] Ușnịșa"), which Rwa lo received from Guru Bha ro during his first visit to Nepal as a means to counter the magical onslaught of the nefarious

relic at Se ra monastery, the Se ra phur zhal dagger (e-mail communication, May 25, 2018). Much more research needs to be done on the history of this intriguing story and its transmission.

52 Ra Yeshé Sengé, The All-Pervading Melodious Drumbeat, 233 (modified for consistency of style); Rwa Ye shes seng ge, Rwa lo rnam thar, 258-59: de'i tshe 'bre ban tshul gsum gyis bla ma la phrag dog langs te mthu rgyas byas / 'bres sbyin bsreg byas / sum pas gtor ma 'phangs / rkyang pos gtad rgyab nas cho 'phrul gtang ba la / bla mas yi ge bzhi ba'i bsad bzlog bsgom pas mthu phar log ste 'bre smyo / sum pa 'das / rkyang po la mdze byung skad / der khong gsum po rjes 'jug rnams kyis gsang ste. 
Saiva yogin Pūrna nag po ("Full of Darkness"). ${ }^{53}$ Another is the Dug dbang rma bya rgyas pa ("Elaborate Poison-Powered Peacock"), which is the sixteenth and final title among Rwa lo's compositions listed in his Thim yig (see 3.3 above). ${ }^{54}$ It comprises an extensive collection of more than fifty individual methods for neutralizing the "poison" (viṣa) of demons and other material and psychological evils.

\section{Conclusion}

Among the multiple traditions of Vajrabhairava and Yamāri/Yamāntaka that have existed in Tibet from as early as the tenth century (e.g. Zhang, Gnyos, Rwa, Skyo, Mal, etc.), ${ }^{55}$ the tradition of Rwa lo tsā ba has long been distinguished as superior, but until recently almost nothing was known of its earliest literature; that is, of course, beyond Rwa lo tsā ba's canonical translations and the elaborate hagiography of his controversial life and mission. The several individual manuscript versions of the Rwa pod that are now available reveal a

53 See episode in Rwa Ye shes seng ge, Rwa lo mam thar, 15-17; Ra Yeshé Sengé, The AllPervading Melodious Drumbeat, 13-15. The text can be found in RP1 (054), Uș̣ișa rwa lugs kyi gdams pa, 267v1-271v1; cf. RP2 (1.087 and 2.033). The deity here is Ușnīṣacakravarti (Tib. Gtsug tor 'khor los sgyur ba), specifically in the form of Vajroṣnīṣacakravarti, one of the ten wrathful guardians (krodha, Tib. khro bo). He protects the zenith of the mandala. See Lokesh Chandra, ed., Dictionary of Buddhist Iconography (New Delhi: International Academy of Indian Culture and Aditya Prakashan, 1999-2005), 13:3747-58.

54 See Rwa Ye shes seng ge, Rwa lo rnam thar, 206 and 223; Ra Yeshé Sengé, The All-Pervading Melodious Drumbeat, 188 and 202. For references in the Rwa pod, see note 38 above.

55 These are namely the traditions (lugs) originating with the early translators Zhang cog gru lo tsā ba Shes rab bla ma (tenth/eleventh century), Gnyos lo tsā ba Yon tan grags (b. ca. 973), Rwa lo tsā ba Rdo rje grags, Skyo 'od kyi 'byung gnas (eleventh/twelfth century), and Mal gyo lo tsā ba Blo gros grags pa (eleventh/twelfth century), sometimes referred to also as the Sa lugs after Mal gyo lo tsā ba's most famous disciple, Sakya Paṇdita (1182-1251). Other traditions include the Nag tsho lugs of Nag tsho lo tsā ba; the Ba ri lugs of Ba ri lo tsā ba Rin chen grags (1040-1112); the 'Gar [Mgar] lugs of Chos sdings pa Gzhon nu rdo rje (alias Sākya dpal, 1180-1240), a subsect of the Gnyos lug; and the Ldong lugs of Ldong ston Shes rab dpal (thirteenth century), a subsect of both the Rwa and Skyo lugs. Histories of these traditions, in varied detail, can be found in Tāranātha, Rgyud rgyal gshin rje gshed skor gyi chos 'byung, 78-120 and 136-38; 'Jam mgon A myes zhabs, Dpal gshin rje'i gshed skor gyi dam pa'i chos byung ba'i tshul legs par bshad pa 'jam dpal chos kun gsal ba'i nyin byed, 141-63 and 209-33; and 'Jam dbyangs bzhad pa'i rdo rje (1648-1722), Dpal rdo rje 'jigs byed kyi chos 'byung khams gsum rnam par rgyal ba dngos grub kyi gter mdzod, in Gsung 'bum of 'Jam dbyangs bzhad pa'i rdo rje (Karnataka, India: Drepung Gomang Library, 2015), vol. 5 (ca), 116-25 and 129-53. 
complex of vital works - tantric commentaries, instructional guides, and an extensive array of ritual texts (abhiṣeka, sādhana, maṇdala, yantra, homa, etc.) that illuminate the hitherto enigmatic contours of this unique transmission in Tibet, once considered lost; its full story remains to be told. I have offered in this chapter merely a sketch of some of its salient features in the hope of encouraging further research into Rwa's seminal tradition and the original works that helped to shape it.

\title{
Appendix 1: Translation
}

\author{
The Four Syllables for Slaying and Repelling \\ [Rwa's Resting Concentration Practice $]^{56}$
}

Homage to the Guru and Glorious Vajrabhairava.

[Narrative:] After requesting the Nepali Guru Mahākarunika for the complete instructions on Vajrabhairava, Rwa lo tstsha [tsā] ba Rdo rje grags offered him eight ounces of gold. Upon accepting the offer, [the Guru] bestowed on [Rwa lo tsā ba] the oral instructions [called] "The Four Syllables for Slaying and Repelling," a rite of fierce magical assault, a wondrous secret oral instruction, a most profound dark counteracting force. Wishing to cultivate this, [Rwa lo tsā ba] began at sunset the following day. He visualized Vajrabhairava [arising] from the state of emptiness, his body black with one face, two arms, three eyes, holding with both hands at his heart a blazing sword, a sharp golden ax with

56 In his eighteenth-century history of the Vajrabhairava cycle, 'Jam dbyangs bzhad pa lists a text entitled Bsam gtan nyal chog ("Resting Concentration Practice") among the writings of a certain 'Phags pa, who may very well have been the eminent Sa skya scholar and holder of the Rwa transmissions 'Phags pa Blo gros rgyal mtshan (1235-80). Whether this title refers to the same work translated here is uncertain. It is curious, though, that the "Four Syllables for Slaying and Repelling” is not listed by title in either the Thim yig of Rwa lo tsā ba or in Rwa Shes rab rgyal mtshan's expanded Dkar chag, suggesting that Rwa lo tsā ba may not have actually authored the text. The text's narrative voice seems to point to that conclusion as well. So the fact that 'Phags pa or someone other than Rwa lo could have been its author (or one of its authors) remains a very real possibility. For the reference in 'Jam dbyangs bzhad pa, see his Dpal rdo rje 'jigs byed kyi chos 'byung khams gsum rnam par rgyal ba dngos grub kyi gter mdzod, 143 and also 514, where the same title and its attribution appear in a list of Vajrabhairava teachings received by 'Jam dbyangs chos rje Bkra shis dpal ldan (1379-1449), an important disciple of Tsong kha pa (1357-1419) who was the founder and first abbot of 'Bras spungs monastery. 
his huge left thumb, [and] a thick silver anvil (dngul gyi gtan pa mkhregs pa) [between] his fingers; [he had] long matted black hair, half of which concealed his body, the [other] half fluttered in the sky above; atop his sword blazed a roaring world-destroying cosmic fire (bskal pa'i me) scorching all harmful enemies and obstructors; [he stood] baring his fangs, rolling his tongue, his two enormous legs the size of Mt. Meru spread wide apart. At the deity's heart, [Rwa lo tsā ba] visualized a black HŪM, from which radiated immeasurable rays of light. These light rays transformed into countless ferocious takkirājas ('dod rgyal), ${ }^{57}$ [each] with one face and two arms, brandishing iron hooks in their right [hands] and nooses in their left. He visualized them summoning the Dharma Protectors and, with their iron hooks, grabbing by the heart the Buddhist and Bon po priests and other enemies and obstructors who had caused him harm, and binding them at the waist with their nooses. [Rwa lo tsā ba] visualized them being carried to [Vajrabhairava's] silver anvil and with his golden ax reducing entirely their flesh and bones to a bloody pulp.

[Instruction:] When protecting your own guru, friends, and companions, your defenses will become supreme by meditating on [the figure of Vajrabhairava] from his matted hair to his body. Concentrate also on the demons ('dre) present, the "king" spirits (rgyal po) and others of that sort; summon them and then imagine they are subdued. This is the mantra to be spoken: E s[v]A BHYO BZLOG. Count this out using an actual mālā. If you are competing against a powerful māntrika or find yourself in terrible danger, do a thousand recitations of this mantra, or at the very least a hundred of them. To merely defend yourself, a hundred [recitations], or at least twenty, but it is enough just to remember it. Recite it without interruption on the twenty-ninth day of the month. ${ }^{58}$ There is no need to establish a formal meditation session, nor invite the deity at the start, nor [maintain a state of] nonconceptuality, and so forth. [This] is also called "Rwa's Resting Concentration Practice" (rwa'i bsam gtan nyal chog). It is a māntrika's tool for killing, so it is crucial not to let it fall into the hands of a shady person (mi nag pa). Since [this practice] can harm anyone who wields its string [of mantra syllables], it should be kept secret. When the time comes to transmit this [practice], bestow it [only] after you have

57 The text clearly indicates the plural here, even though Krodha Takkirāja (alias Kāmarāja) is usually rendered as a single deity (either blue or red with two or four arms) commonly depicted in the retinue of Mahākāla but also as one of ten wrathful guardians of monasteries and other sacred Buddhist spaces. For descriptions and sample images, see Lokesh Chandra, Dictionary of Buddhist Iconography, 12:3498-3502.

58 Traditionally in Tibet, the twenty-ninth day of the lunar month is the special day for requesting the Dharma Protectors to dispel demons and remove obstacles. See Philippe Cornu, Tibetan Astrology, trans. Hamish Gregor (Boston: Shambhala Publications, 1997), 275. 
offered a communal feast (ganacakra) to the dākinīs and a mandala of gold to the guru. Profound. Ithi [Skt. iti].

[Colophon:] ${ }^{59}$ In accordance with the seal of secrecy, [I] received [this] after offering Rje btsun seng ge a mandala of gold. If some vow-keeper other than me ${ }^{60}$ wishes to have this [practice] bestowed, he should bring with him a large and exalted mandala of gold. When that occurs, and if the recipient is a worthy vessel, the teaching that is to be granted will be singularly pure.

\title{
Appendix 2: Transcription
}

\section{Abbreviations}

RP1: Rdo rje 'jigs byed kyi rwa'i thim yig rwa los mdzad pa. [266v.4]

RP2: Rwa khrid mkha' 'gro snyan brgyud, vol. 1 (no. 086). \{1v.1\}

RNC: Rwa lo’i bzlog pa bsam gtan nyal chog. <1v.1>

\author{
yi ge bzhi ba'i bsad bzlog bzhugs so \\ [rwa'i bsam gtan nyal chog]
}

[266v.4] bla ma dpal rdo rje 'jigs byed la phyag 'tshal lo / bla ma bal po thugs rje chen po la / rwa lo tstsha ba rdo rje grags kyis rdo rje 'jigs byed kyi gdams pa ma lus par zhus pa'i ${ }^{\mathrm{b}}$ mthar $^{\mathrm{c}}$ gser srang ${ }^{\mathrm{d}}$ brgyad 'bul bar zhal gyis bzhes nas gnang ba'i gdams ngag yi ge bzhi pa’i gsad bzlog / drag po mngon spyod kyi las / gsang ba'i man ngag rmad du byung ba / yang gsang mthu bzlog nag po 'di bsgom par 'dod pas / dus ${ }^{\mathrm{f}}$ nyi ma nub khar' ${ }^{\mathrm{g}}$ kha nub tu phyogs te / stong pa'i ngang las ${ }^{\mathrm{h}}$ rdo rje 'jigs byed sku mdog nag po zhal gcig phyag gnyis pa / spyan gsum pa phyag ${ }^{i}$ gnyis $^{j}$ thugs kar ral gri $\mathrm{me}^{\mathrm{k}}$ 'bar ba bsnams <2r> pa g.yon pa mtheb ${ }^{l}$ chen gser gyi sta $\mathrm{re}^{\mathrm{m}} \mathrm{rno}^{\mathrm{n}}$ ngar dang ldan pa / mdzub mo dngul gyi gtan ${ }^{\mathrm{o}}$ pa mkhregs pa ${ }^{\mathrm{p}}$ rgya bde ${ }^{\mathrm{q}}$ ba / ral pa nag po ban bun gyi phyed kyis lus khebs ${ }^{\mathrm{r}}$

59 This colophon is not included in manuscript RCN. In its place is inserted a brief transmission lineage. See note 45 above.

60 I have yet to identify the "me" in this passage, but it is plausible that the teacher named here as Rje btsun seng ge might refer to Rong pa Shes rab seng ge (1251-1315), son and chief disciple of Rong pa Rgwa lo rnam rgyal rdo rje (1203-82), both of whom were influential patriarchs of the Western Rwa tradition. But, alas, without some other more satisfying piece of evidence, there are just too many different "Seng ge's" listed in the Rwa lineages down through the ages to make a conclusive determination. 
pa / phyed nam mkha' la yeng yeng phyo ba / ral pa'i phyi la bskal pa’i me dmar 'ur 'ur' 'phro' bas dgra bgegs gnod byed thams cad bsreg pa [267r] mche pa ${ }^{\mathrm{u}}$ rnam par gtsigs zhing ljags 'dril ba zhabs gnyis bsgrad pa shin tu che ba'i ${ }^{\mathrm{v}}$ ri rgyal tsam du bsgom pa'i thugs kar hūm nag po ${ }^{\mathrm{w}}$ gcig bsgom / de las 'od zer dpag tu med pa 'phros pas / 'od zer rnams khro bo 'dod ${ }^{\mathrm{x}} \operatorname{rgyal}^{\mathrm{y}}$ zhal gcig phyag gnyis $^{\mathrm{z}}$ g.yas lcags kyu dang g.yon $<2 \mathrm{v}>$ zhags pa thogs pa grangs med par gyur ${ }^{\text {aa }}$ nas de rnams kyis bdag la gnod pa'i ban bon dang dgra bgegs ${ }^{\text {ab }}$ sogs kyis chos $\left\{2 \mathrm{r}\right.$ \} skyong rnams bkug ${ }^{\text {ac }}$ lcags kyus snying ${ }^{\text {ad }}$ nas bzung / zhags pas sked ${ }^{\text {ae }}$ nas bdams $^{\text {af }}$ dngul gyi gtan ${ }^{\text {ag }}$ pa'i kha ${ }^{\text {ah }}$ phyen $^{\text {ai }}$ ongs pa dang / gser gyi sta res sha rdzogs rus $\mathrm{pa}^{\mathrm{aj}} \mathrm{rdzogs}^{\mathrm{ak}} \mathrm{tu}^{\mathrm{al}}$ dmar mdag $^{\mathrm{am}}$ dum bur gtubs ${ }^{\text {an }}$ par bsam / rang gi bla ma dang gnyen ${ }^{\text {ao }}$ grogs $^{\text {ap }}$ bsrung na ${ }^{\text {aq }}$ ral pa $^{\text {ar }}$ dang lus $\mathrm{kyi}^{\text {as }}$ bar du bsgom pas bsrung ba'i mchog tu 'gyur ro / rgyal po la sogs pa'i 'dre ${ }^{\text {at }}$ yod kyang ${ }^{\text {au }}$ dmigs pas bkug nas ${ }^{\text {av }}$ btul $^{\text {aw }}<3$ r $>$ bar bsam ${ }^{\text {ax }} /$ sngag ni / e sa ${ }^{\text {ay }}$ bhyo bzlog / ces pa 'di phreng ba phyir la ${ }^{\mathrm{az}}$ phul zhing ${ }^{\mathrm{ba}}$ bgrang / sngags $\mathrm{pa}^{\mathrm{bb}} \mathrm{mthu}^{\mathrm{bc}}$ 'gran $^{\mathrm{bd}}$ pa'am / $^{\text {'am }}$ nyam nga ba che ${ }^{\text {be }}$ na stong ngam ${ }^{\text {bf }}$ brgya rtsa re tsam ${ }^{\text {bg }}$ bzla / rang bsrung ba ${ }^{\text {bh }}$ tsam la brgya'am nyi shu rtsa re'am ${ }^{\text {bi }} /$ dran pa $^{\text {bj }}$ tsam gyis ${ }^{\text {bk }}$ kyang chog / zla ba mar ngo'i nyer dgu la ma chag par bzlas / thun 'jog khar lha gshegs gsol dang mi dmigs pa sogs kyang mi dgos ${ }^{\text {bl }}$ / rwa'i bsam gtan nyal chog ces kyang ${ }^{\text {bm }}$

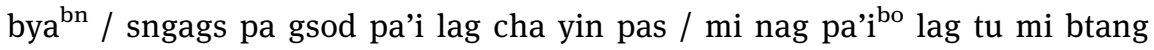
ba $^{\text {bp }}$ gal che ${ }^{\text {bq }} /$ 'phreng thogs yongs la gnod pas ${ }^{\text {br }}$ gsang bar bya ${ }^{\text {bs }} /$ ' $^{\text {bt }}{ }^{\text {bpel }}$ ba'i dus su / mkha' 'gro tshogs 'khor ${ }^{\text {bu }}$ dang / bla ma la gser gyi ${ }^{\text {bv }}$ maṇula phul nas ${ }^{\text {bw }}$ zhu'o $^{\text {bx }}<3 \mathrm{v}>/$ zab ithi [sic] / bka' rgya bzhin du / rje btsun sengge la gser gyis ${ }^{\text {by }}$ maṇdala phul nas zhus pa yin pas / dam ldan 'ga' zhig bdag las 'di stsal parbz 'dod na gser gyi maṇula rgya che la dpangs mtho ba khyer la shog cig / de byung zhing snod [267v] dang ldan na sbyin ${ }^{\text {ca }}$ par bya ba'i chos yang dag pa gcig go ${ }^{\mathrm{cb}} / /$

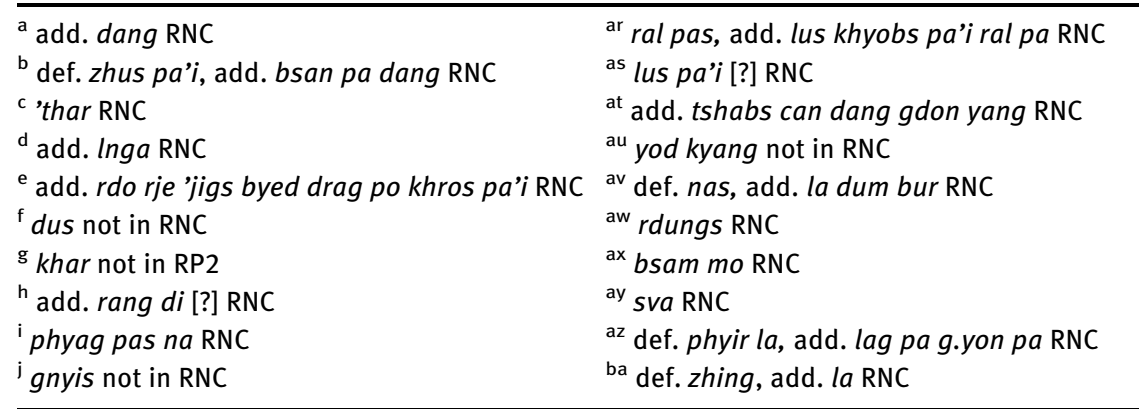


${ }^{\mathrm{k}}$ me not in RNC

' mthob RP2; 'theb RNC

${ }^{\mathrm{m}}$ re chen po RNC

"rno ba'i RNC

o brtan RNC

${ }^{\mathrm{p}}$ mkhregs pa not in RNC

${ }^{\mathrm{q}}$ che RNC

${ }^{\mathrm{r}}$ khyebs RNC

s bun bun RNC

t'phros RNC

"mche ba RP2; 'che ba RNC

${ }^{v}$ che ba RNC

${ }^{w}$ add. chen po RNC

$x$ 'dod pa'i RNC

y rgyal po RNC

${ }^{z}$ gnyis pa RNC

aa def. gyur, add. sprul RNC

${ }^{\text {ab }}$ def. ban bon dang dgra bgegs; add. gnod pa'i dgrong dang gnod byed RNC

ac add. nas RNC

ad add. kha RNC

ae ske RP2

${ }^{\text {af }}$ bsdams RP2; add. nas RNC

ag brtan RNC

ah khar RNC

ai khyer RP2; khyer nas RNC

${ }^{\text {aj }}$ pa not in RNC

ak rjog RP2

al def. tu, add. la RNC

am 'dag 'dag RNC

an rdungs RNC

ao dang gnyen not in RNC

ap grogs po, add. nye grog [?] chen 'khor g.yog la sogs RNC

${ }^{\text {aq }}$ add. rang gi RNC bb def. pa, add. nag RNC

bc 'thu RNC

bd def. 'gran; add. can dang 'dres RNC

be yod RNC

bf $m a$ RNC

${ }^{\text {bg }}$ tsam not in RNC

bh $b a$ not in RNC

bi def. 'am, add. bzla RNC

bj dran pas RNC

${ }^{\mathrm{bk}}$ tsam gyis not in RNC

bl lines zla ba . . . mi dgos inserted as mchan bu handwritten in $d b u$ can script at bottom of folio in RNC

${ }^{\mathrm{bm}}$ kyang not in RNC

bn bya ba'di RNC

bo def. pa'i, add. gi RNC

bp def. mi btang ba, add. ma shor ba RNC

bq che'o RNC

br add. kun tu RNC

bs bya'o RNC

bt add. la bka'dam po yod pas RNC

bu def. 'khor, add. gtor RNC

bv gyi not in RP2; gser gyi not in RNC

bw def. nas, add. la RNC

bx def. 'o, add. zhing bla ma'i ngag las bzung ba ma gtogs pa yi ger mi 'bri ba'i bka' rgya yod / phyis kyang 'di [?] rgya yod ces kyang bsang bar bya'o // rwa nas brgyud nas / rgya ston rin po che das [= des?] dpal ldan grags pa / rje btsun dam pa nam mkha' lhun grub bzang po / des bdag [b]tsun pa bkra shis rin chen la gnang pa'o // dge sogs 'phel RNC by gyi RP2

bz rtsal bar RP2

ca spyin RP2

${ }^{\mathrm{cb}}$ concluding lines zab ithi [sic] . . gcig go not in RNC 


\section{Appendix 3: Figures}

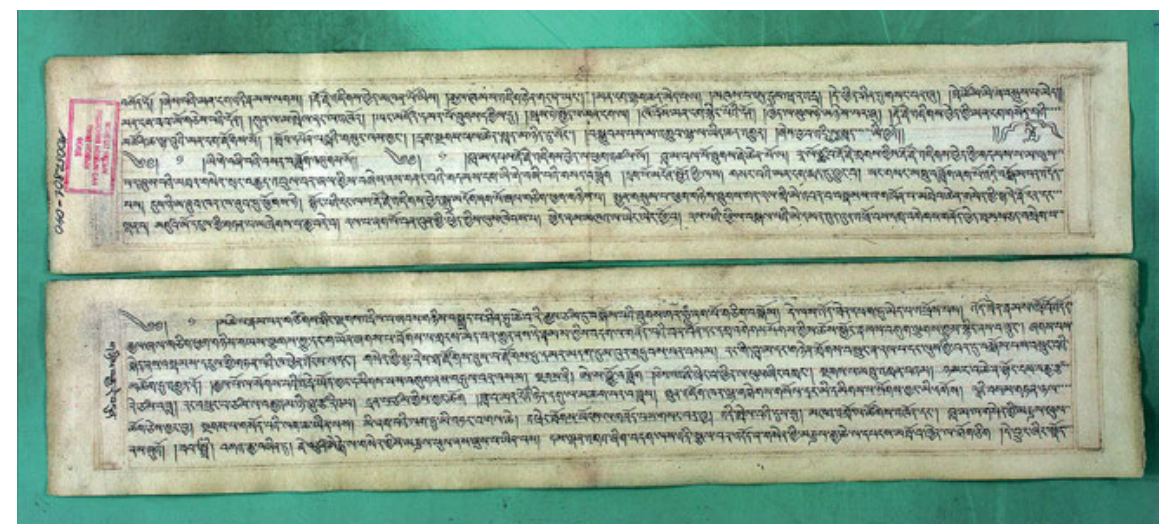

Figure 1: Folios 266v and 267r of the Yi ge bzhi ba'i bsad bzlog ("Four Syllables for Slaying and Repelling") from Rwa pod manuscript RP1. Image courtesy of the Buddhist Digital Resource Center (BDRC). https://www.tbrc.org/\#!rid=W8LS32375.

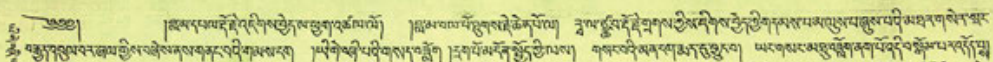

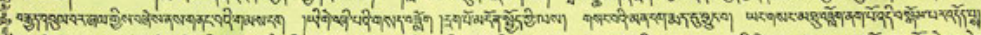

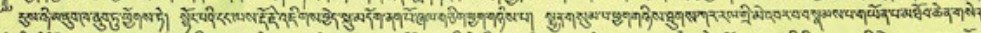

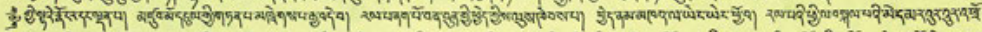

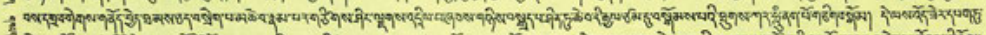

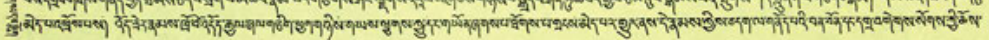

2che

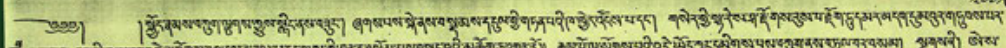

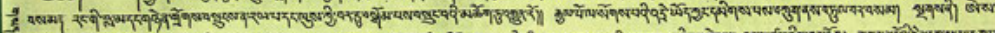



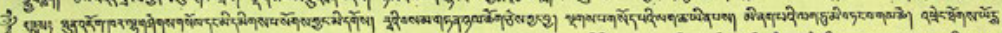

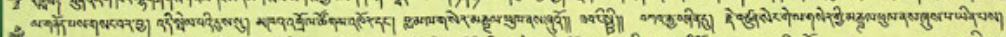

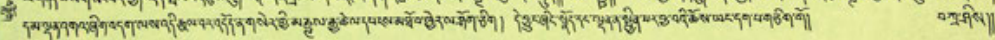

Figure 2: Folios 1v and 2r of the Yi ge bzhi ba'i bsad bzlog ("Four Syllables for Slaying and Repelling") from Rwa pod manuscript RP2. Image courtesy of the Buddhist Digital Resource Center (BDRC). https://www.tbrc.org/\#!rid= W4CZ302660. 

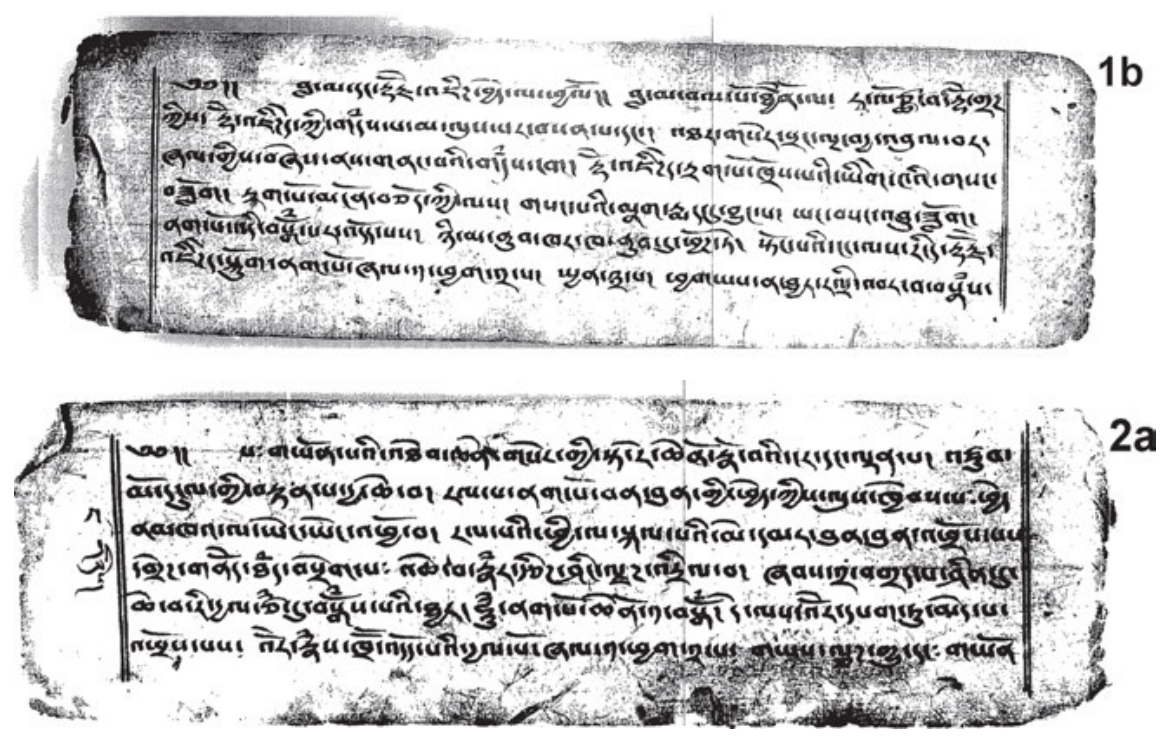

Figure 3: Folios 1v and 2r of Rwa lo'i bzlog pa bsam gtan nyal chog ("Rwa's Repelling Rite, Resting Concentration Practice") from independent manuscript RCN. Images courtesy of the Buddhist Digital Resource Center (BDRC). https://www.tbrc.org/\#!rid=W1CZ1303.

\section{Bibliography}

\section{Tibetan Sources}

'Bri gung dpal 'dzin. Chos dang chos ma yin pa rnam par dbye ba'i bstan bcos. Manuscript. BDRC W1CZ885.

'Bri gung dpal 'dzin. Rdo rje 'jigs byed kyi man ngag gi chos skor. Manuscript. BDRC W3CN2615.

Bstan 'dzin phun tshogs, ed. 'Bras spungs dgon du bzhugs su gsol ba'i dpe rnying dkar chag. 2 vols. Beijing: Mi rigs dpe skrun khang, 2004. BDRC W28949.

Fifth Dalai Lama (Ngag dbang blo bzang rgya mtsho). Gsung-'bum. Vols. 1-4 (ka-ga), Zab dang rgya che ba'i dam pa'i chos kyi thob yig gang ga'i chu rgyun. Dharamsala: Nam gsal sgron ma, 2007. BDRC W2CZ5990.

'Khon ston Dpal 'byor lhun grub. 'Jam dpal gshin rje gshed skor gyi bla ma brgyud pa'i chos 'byung gdul bya'i re 'dod skong ba yid bzhin nor bu'i 'phreng ba. Dharamsala: Library of Tibetan Work \& Archives, 2005. BDRC W1CZ2855.

'Jam dbyangs bzhad pa'i rdo rje. Dpal rdo rje 'jigs byed kyi chos 'byung khams gsum rnam par rgyal ba dngos grub kyi gter mdzod. In Gsung 'bum of 'Jam dbyangs bzhad pa'i rdo rje, vol. 5 (ca), 1-835. Karnataka: Drepung Gomang Library, 2015. BDRC W1KG24277. 
'Jam dbyangs mkhyen brtse'i dbang po. Man ngag gces btus sna tshogs phyogs gcig tu bsgrigs pa 'dod rgu kun 'byung dbang rgyal nor bu'i phreng ba. In The Collected Works (Gsung 'bum) of the Great 'Jam-dbyañs Mkhyen-brtse'i-dban-po, vol. 20, 361-554. Gangtok: Gonpo Tseten, 1977-80. BDRC W21807.

'Jam mgon A myes zhabs Ngag dbang kun dga' bsod nams. Dpal gshin rje'i gshed skor gyi dam pa'i chos byung ba'i tshul legs par bshad pa 'jam dpal chos kun gsal ba'i nyin byed. In Gsung 'bum, vol. 15 (ba), 105-246. Kathmandu: Sa skya rgyal yongs gsung rab slob gnyer khang, 2000. BDRC W29307.

'Jam mgon Kong sprul Blo gros mtha' yas. Gter ston brgya rtsa'i rnam thar [=Zab mo'i gter dang gter ston grub thob ji ltar byon pa'i lo rgyus mdor bsdus bkod pa rin chen vaidūrya'i phreng ba]. In Rin chen gter mdzod chen mo, vol. 1, 341-765. New Delhi: Shechen Publications, 2007-16. Accessed July 22, 2019. http://rtz.tsadra.org/index. php/Terdzo-KA-006.

Rwa lo tsā ba Rdo rje grags. Rwa lo'i bzlog pa bsam gtan nyal chog. Manuscript. BDRC W1CZ1303 (RCN).

Rwa lo tsā ba Rdo rje grags. Rwa pod. Ka nas tu / Rdo rje 'jigs byed kyi rwa'i thim yig rwa los mdzad pa. Manuscript. BDRC W8LS32375 (RP1).

Rwa lo tsā ba Rdo rje grags. Rwa pod. Rwa khrid mkha' 'gro snyan brgyud. [A] Manuscript. BDRC W4CZ302660 (RP2); [B] Manuscript. BDRC W4CZ58529 (RP3); [C] Manuscript. BDRC W8LS29654 (RP4).

Rwa Ye shes seng ge. Rwa lo rnam thar [=Mthu stobs dbang phyug rje btsun rwa lo tsā ba' $i$ rnam par thar pa kun khyab snyan pa'i rnga sgra]. Xining: Mtsho sngon mi rigs dpe skrun khang, 1989.

Tāranātha. Rgyud rgyal gshin rje gshed skor gyi chos 'byung rgyas pa yid ches ngo mtshar. In Collected Works by Jonang Master Jetsun Tāranātha, vol. 11, 1-138. Beijing: Krung go'i bod rig pa dpe skrun khang, 2008. BDRC W1PD45495.

\section{Secondary Sources}

Beyer, Stephan. The Cult of Tārā: Magic and Ritual in Tibet. Berkeley, CA: University of California Press, 1973.

Bühnemann, Gudrun. "The Six Rites of Magic." In Tantra in Practice, edited by David Gordon White, 447-62. Princeton, NJ: Princeton University Press, 2000.

Chandra, Lokesh, ed., Dictionary of Buddhist Iconography. 15 vols. New Delhi: International Academy of Indian Culture and Aditya Prakashan, 1999-2005.

Chandra, Lokesh, ed., Materials for a History of Tibetan Literature. 3 vols. 1963. Reprint, New Delhi: International Academy of Indian Cultures, 1981.

Clough, Bradley S. "The Higher Knowledges in the Pāli Nikāyas and Vinaya." Journal of the International Association of Buddhist Studies 33, nos. 1/2 (2010/2011): 409-33.

Cornu, Philippe. Tibetan Astrology. Translated by Hamish Gregor. Boston: Shambhala Publications, 1997.

Cuevas, Bryan J. “The Calf's Nipple (Be'u bum) of Ju Mipam ('Ju Mi pham): A Handbook of Tibetan Ritual Magic.” In Tibetan Ritual, edited by José I. Cabezón, 165-86. New York: Oxford University Press, 2010. 
Cuevas, Bryan J. "Illustrations of Human Effigies in Tibetan Ritual Texts: With Remarks on Specific Anatomical Figures and Their Possible Iconographic Source.” Journal of the Royal Asiatic Society 21, no. 1 (2011): 73-97.

Cuevas, Bryan J. "The Politics of Magical Warfare." In Faith and Empire: Art and Politics in Tibetan Buddhism, edited by Karl Debreczeny, 171-89. New York: Rubin Museum of Art, 2019.

Cuevas, Bryan J. "Rva lo tsā ba and His Biographers." In The Illuminating Mirror: Tibetan Studies in Honour of Per K. Sørensen on the Occasion of His 65th Birthday, edited by Olaf Czaja and Guntram Hazod, 57-79. Wiesbaden: Dr. Ludwig Reichert Verlag, 2015.

Davidson, Ronald M. Tibetan Renaissance: Tantric Buddhism in the Rebirth of Tibetan Culture. New York: Columbia University Press, 2005.

Gómez, Luis 0. "The Bodhisattva as Wonder-Worker." In Prajñāpāramitā and Related Systems: Studies in Honor of Edward Conze, edited by Lewis Lancaster, 221-61. Berkeley, CA: Berkeley Buddhist Studies Series, 1977.

Goudriaan, Teun. Māyā Divine and Human: A Study of Magic and its Religious Foundations in Sanskrit Texts, with Particular Attention to a Fragment on Viṣnu's Māyā Preserved in Bali. Delhi: Motilal Banarsidass, 1978.

Granoff, Phyllis. "The Ambiguity of Miracles: Buddhist Understandings of Supernatural Power." East and West 46, nos. 1/2 (1996): 79-96.

Jacobsen, Knut A., ed. Yoga Powers: Extraordinary Capacities Attained Through Meditation and Concentration. Leiden: Brill, 2012.

Karsten, Joachim Günter. “A Study of the Sku-'bum/T’a-erh ssu Monastery in Ch'ing-hai.” PhD diss., University of Auckland, 1996.

Kuijp, Leonard van der. "The Bird-faced Monk and the Beginnings of the New Tantric Tradition, Part One." In Tibetan Genealogies: Studies in Memoriam of Guge Tsering Gyalpo (1961-2015), edited by Guntram Hazod and Shen Weirong, 403-50. Beijing: China Tibetology Publishing House, 2018.

Kuijp, Leonard van der. "The Bird-faced Monk and the Beginnings of the New Tantric Tradition, Part Two." Journal of Tibetology 19 (2018): 86-127.

Kuranishi, Kenichi. "Śrīdhara and His Works on the Yamāri Cycle." In Esoteric Buddhist Studies: Identity in Diversity Proceedings of the International Conference on Esoteric Buddhist Studies, Koyasan University, 5 Sept.-8 Sept. 2006, 179-83. Japan: Koyasan University, 2008.

Kuranishi, Kenichi. "Yantras in the Buddhist Tantras - Yamāritantras and Related Literature." In Pușpikā: Tracing Ancient India, through Texts and Traditions. Contributions to Current Research in Indology, vol. 1, Proceedings of the First International Indology Graduate Research Symposium (September 2009, Oxford), edited by Nina Mirnig, Péter-Dániel Szántó, and Michael Williams, 265-81. Oxford: Oxbow Books, 2013.

Patton, Thomas Nathan. The Buddha's Wizards: Magic, Protection, and Healing in Burmese Buddhism. New York: Columbia University Press, 2018.

Ra Yeshé Sengé. The All-Pervading Melodious Drumbeat: The Life of Ra Lotsawa. Translated by Bryan J. Cuevas. New York: Penguin Classics, 2015.

Sanderson, Alexis. "The Śaiva Age: The Rise and Dominance of Śaivism during the Early Medieval Period." In Genesis and Development of Tantrism, edited by Shingo Einoo, 41-349. Tokyo: Institute of Oriental Culture, University of Tokyo, 2009. 
Schwieger, Peter. "Black Magic in Tibetan Buddhism." In Historical and Philological Studies of China's Western Regions, no. 3, edited by Shen Weirong, 169-85. Beijing: Science Press, 2010.

Siklós, Bulcsu. The Vajrabhairava Tantras: Tibetan and Mongolian Versions, English Translation and Annotations. Tring: The Institute of Buddhist Studies, 1996.

Sinclair, Iain. "War Magic and Just War in Indian Tantric Buddhism." Social Analysis 58, no. 1 (2014): 149-66.

Sperling, Elliot. “'Orientalism' and Aspects of Violence in the Tibetan Tradition.” In Imagining Tibet: Perceptions, Projections, and Fantasies, edited by Thierry Dodin and Heinz Räther, 317-29. Boston: Wisdom Publications, 2001.

Türstig, Hans-Georg. "The Indian Sorcery Called Abhicära." Wiener Zeitschrift für die Kunde Südasiens 29 (1985): 69-117. 